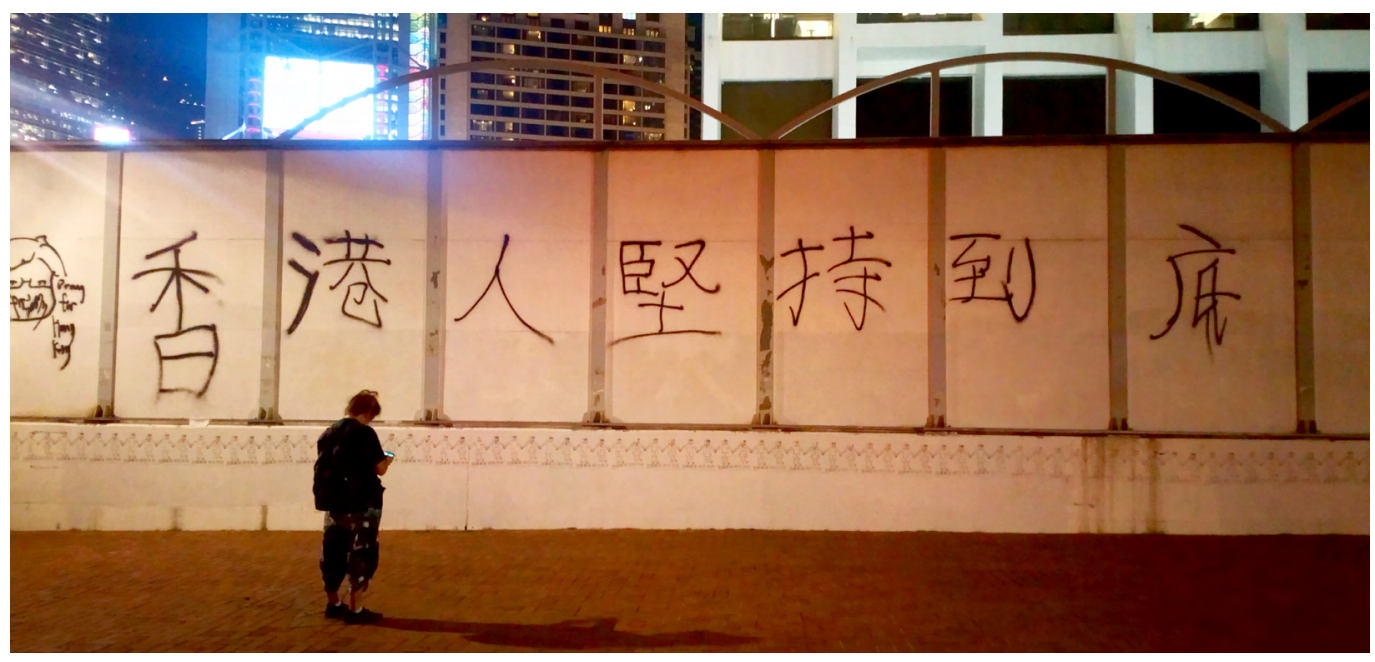

Graffiti at the General Post Office Building. PC: Judith Pernin.

\section{Phantom Sounds, Haunting Images The Afterlife of Hong Kong's Visual Protest Culture}

\section{Judith PERNIN}

Before the enactment of the National Security Law, recordings of and artistic productions about the 2019 prodemocracy movement were thriving on Hong Kong's streets, university campuses, in social media, the press, and the cultural sphere at large. Now that protests have almost disappeared from public space, and symbols and slogans are criminalised, what happens to the profuse and popular visual culture generated by the protests? This essay revisits the rapidly changing landscape of the visual culture of Hong Kong protests and examines how some of its components have been affected by political developments, leading to a shift in its regime of visibility.

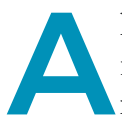
lmost three years on, the sounds and images of the 2019 Hong Kong protest movement are still haunting. Powerful, imaginative, and long-lasting, the half-year mobilisation and its iconography are hard to forget, and the ongoing political crackdown keeps our memory alive with constant republications of photographs and video clips of the events. Since the outbreak of the Covid-19 pandemic and the proclamation of the National Security Law (NSL) on 30 June 2020, protests have, however, almost disappeared from Hong Kong's public spaces. Protest symbols and slogans are now criminalised and their representation has become politically sensitive. As a result, many films, books, and artworks have vanished from screening venues, shops, and libraries. In this new context, any prodemocracy discourses and artefacts are likely to attract unwanted attention. 


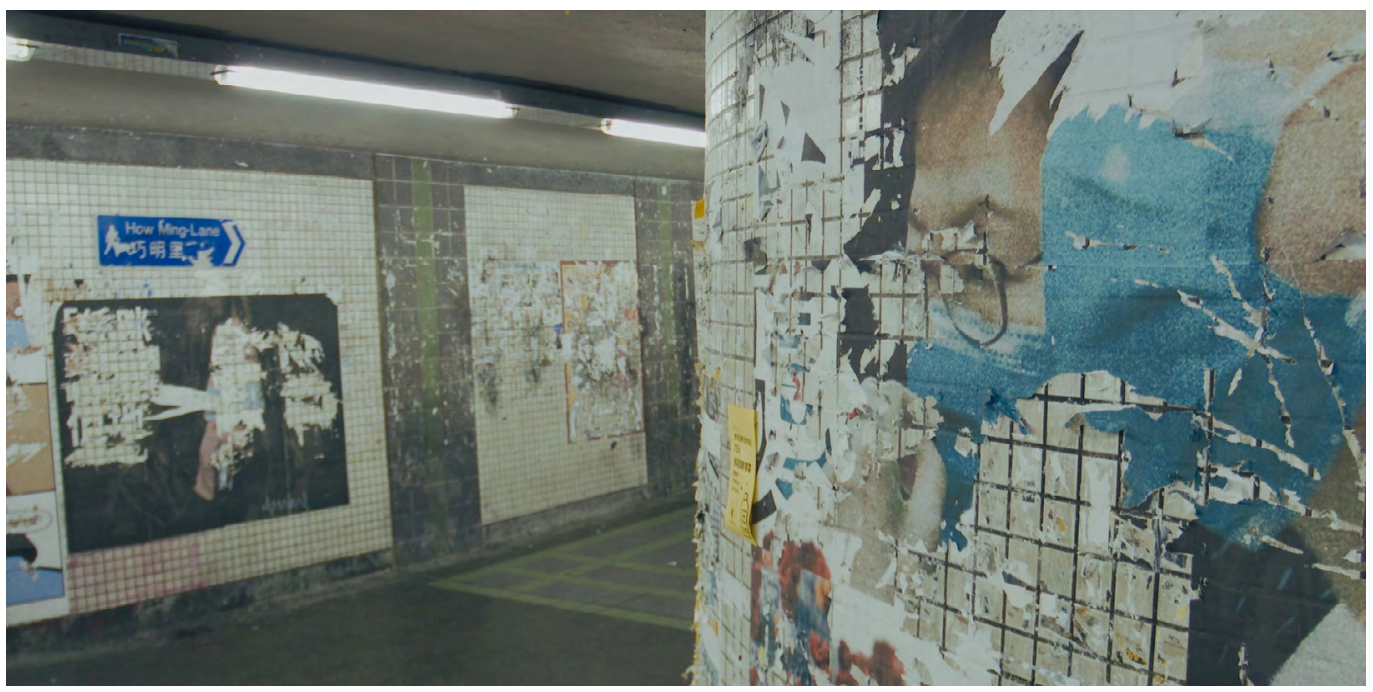

Traces of a Lennon Wall in Fear(less) and Dear (誠 惶(不)誠恐, 親愛的), 2021. PC: Anson Mak.

The Pillar of Shame statue removal saga, the clampdown on prodemocracy news outlets, the revamping of secondary school curricula, and the withdrawal of books on the Tiananmen movement from public library shelves show that a sweeping eradication effort is under way. This raises concerns about the possibility of maintaining (at least in public) some of the cornerstones of Hongkongers' collective identity, such as the commemoration of the 1989 crackdown in Beijing, as well as uncensored accounts of the recent history of prodemocracy movements.

This process of erasure targets physical objects, images, and texts that used to be widely visible online and offline. What happens to a profuse and popular protest visual culture when it is suddenly outlawed or, rather, when it faces unprecedented legal risk? This essay revisits the rapidly changing landscape of the visual culture of Hong Kong protests and examines how some of its components have been affected by political developments, leading to a shift in its regime of visibility (McGarry et al. 2020). Documentary images (still or moving) from the press, independent filmmakers, and netizens form a great part of this culture. Widely shared, recycled, and appropriated, documentary images depicting the protests circulated online and offline, and inspired or supplemented other creative works such as graffiti, murals, posters, music, and performance art. By no means exhaustive or predictive, this essay considers this diverse media's modes of visibility and authorship and seeks to imagine the afterlife of Hong Kong's visual protest culture in the post-NSL era.

\section{During the Protests: Ephemeral Urban Displays}

Many popular visual productions such as the Prague-inspired Lennon walls were characterised from the beginning of the 2019 protests by ephemerality and collective, anonymous, or pseudonymous authorship. Initiated during the Umbrella Movement, the practice of posting messages on walls adjacent to the Hong Kong Legislative Council (LegCo) building was revived in 2019 and extended to pedestrian subways and bus and Mass Transit Railway (MTR) stations in every Hong Kong neighbourhood (see also Wu's essay in the present issue). Instead of using sticky notes like in 2014, in 2019, protesters drew or printed bigger posters displaying their demands, criticising the 


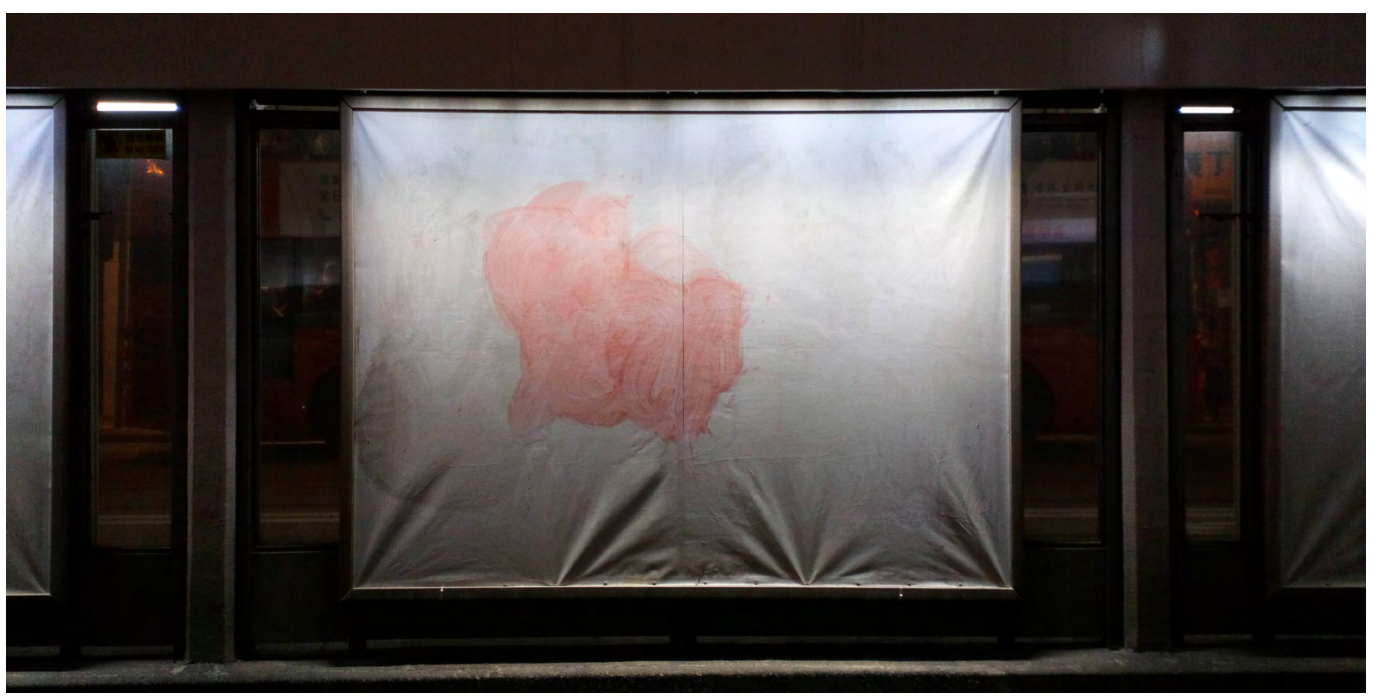

Traces of a slogan after an unsuccessful cleaning operation. PC: Judith Pernin.

police, and mocking the government. Day after day, Lennon walls were set up, vandalised, cleaned up, and reappropriated with new posters, covering vast surfaces in a rapid turnover. Cleaning operations usually failed to make them entirely and durably disappear, and instead created colourful palimpsests of text and images and prompted even larger and bolder displays. The posters themselves were made by ordinary people, artists, or groups who also operated online and usually concealed their identity behind a moniker or collective name.

Soon after the end of the movement, two anonymous books documented these ephemeral displays challenging authorities and urban order (Abaddon 2020; Guardian of Hong Kong 2020). Despite recent recognition of street art through local figures such as the King of Kowloon and the Plumber King, clean, blank walls are the norm in Hong Kong (Cartier 2012; Potts 2021). Aside from Lennon walls, one of the most subversive aspects of the 2019 movement was perhaps protesters' disregard for street cleanliness and orderliness, which was exemplified by political graffiti. While the Umbrella Movement advocated peaceful civil disobedience and was praised for protesters' concern about maintaining hygiene and tidiness, in 2019, protesters responded to police violence by dismantling street furniture and tagging or destroying shop windows, Chinese banks, MTR Corporation property, and businesses linked to Beijing and local triads. The subsequent flurry of cleaning and repair operations did not immediately return these urban canvases to their original blankness. Several photo projects document the easily recognisable traces of protest slogans-once legible and now turned into abstract landscapes and smears rather than being effectively concealed (Gaul 2019; Ho 2020).

\section{Intimidation Strategies in the Post-NSL Context}

Since the enactment of the NSL, a vast campaign to eradicate dissent has been launched in Hong Kong. Despite original claims that the law would affect only a minority of people, the number of trials of democracy advocates indicates the net of justice is wider than before. Even though it is still too early to assess its long-term consequences on freedom of expression in the visual realm, the NSL is so vague and broad in its formulation, it applies to all intellectual, artistic, and cultural productions. Rather 
than being the only tool used to intimidate activists and cultural workers, the NSL has also endorsed and amplified a more general transformation of the overall environment in which such people operate. For instance, the colonial-era Crimes Ordinance is now often used to charge individuals with sedition, and amendments or new laws are allowed to pass in a LegCo deprived of any opposition (see Chan's essay in the present issue). The pro-Beijing press also plays an important role in launching witchhunts against prodemocracy individuals or groups, further increasing political pressure on them (see also Yeung's essay in the present issue).

The case of the documentaries Taking Back the Legislature (佔領立法會; Hong Kong Documentary Filmmakers 2019) and Inside the Red Brick Wall (理大圍城; Hong Kong Documentary Filmmakers 2020) illustrates these mechanisms. Respectively recording the LegCo Occupation of 1 July 2019 and the siege of Hong Kong Polytechnic University in November 2019, these two observational documentaries were authored by an anonymous collective of Hong Kong independent filmmakers. Before the NSL, film distributor Ying E Chi (影意 志) had selected them for its Hong Kong Independent Film Festival (香港獨立電影節) and organised multiple sold-out screenings as category IIB films (not suitable for children and young people) (Van den Troost 2020, 2021; Pernin 2021; Chui 2020).

In July 2020, the festival had difficulty renewing the films' screening certificates with the Office for Film, Newspaper and Article Administration (OFNAA). After months of negotiations, they finally managed to obtain the certificates just hours before the scheduled screenings, with Inside the Red Brick Wall this time in category III (audiences over 18 years). They also had to insert the following disclaimer at the beginning of the films: 'Some of these depictions or acts may constitute criminal offences under prevailing laws. Some of the contents of or commentaries in the film may be unverified or misleading' (Ying E Chi Cinema 2020). In March 2021, pro-Beijing newspaper Takungpao (大公報) accused these documentaries of 'beautifying' the protests and, in April 2021, it made personal attacks against distributor Ying $\mathrm{E}$ Chi and the Taiwan International Documentary Festival 台灣國際紀錄片影展 for screening them
(Takungpao 2021a, 2021b). In June 2021, the guidelines for film censors were updated to incorporate matters pertaining to national security (Hong Kong Government 2021). Finally, in October 2021, the Film Censorship Ordinance was amended to align with the NSL (Ho 2021b). After losing its Arts Development Council funding, Ying E Chi stopped distributing these award-winning documentaries.

While these two films offer a close and compassionate perspective of protesters and ordinary Hongkongers in the face of oppression, they also avoid sensationalising the protests, so the accusation that they 'beautify' them is questionable. More concerning again is the OFNAA's statement, included in the disclaimer that was added before the two films, warning that not only the filmed acts, but also their 'depiction' itself 'may constitute a criminal offence'. Facing attacks from pro-Beijing newspapers and increasing judicial pressure, filmmakers, distributors, and exhibitors have had to disassociate themselves from protest documentaries by keeping a low profile, adopting anonymous authorship, or even relinquishing their rights over their work (see, for instance, Young 2021).

This chilling effect is paralleled in society at large. With the NSL in place, the general climate around protest images and materials has turned to wariness whereas before a relative openness prevailed, especially online. During the protest movement, online forums, social media apps, and video portals such as LIHKG, Facebook, Telegram, Signal, WhatsApp, and YouTube were beaming live broadcasts from news media, debates illustrated by news clips or photographs, netizens' pictures and videos, slogans, memes, songs, as well as practical discussions, schedules, maps, and so on. Some of these materials depicted situations evolving rapidly on the ground and were made for immediate consumption. Quickly outdated, they were also increasingly ephemeral thanks to built-in features that allowed the setting of an expiry time for the posts or the option to circulate them on encrypted channels or within closed groups. This mode of visibility offers protection against the current trends of online surveillance and offline vigilantism, with citizen reporting encouraged by government and pro-establishment figures-for instance, through a new NSL hotline and former 
chief executive C.Y. Leung Chun-ying's own reporting website (HKFP Fast News 2021; Lam and Leung 2019). As soon as protest images are recorded, drawn, tagged, or shared online or offline, they are now exposed to police scrutiny and public reporting. After activists started being investigated for their social media use and protest materials were confiscated, many ordinary people began to worry about their online activities, or their collection of protest memorabilia and equipment, their books, and tattoos, and they proceeded to delete, conceal, send away, or archive them (Ho 2021a).

\section{Video Journalism after the NSL}

Erasure is an even bigger threat to prodemocracy news outlets, which were the source of a sizeable portion of activism and protest visual culture. On the online channels of Radio Television Hong Kong (RTHK 香港電台), Stand News (立場新聞), and Apple Daily (蘋果日報), daily livestreams of brutal clashes were followed by hundreds of thousands of people. In contrast with the Umbrella Movement, in 2019, protest actions became increasingly dangerous, spontaneous, and spread simultaneously in various parts of Hong Kong.

News reporting was also impacted by the forceful police response and brutality towards journalists, with many operations specifically targeting those working for prodemocracy outlets (Luqiu 2021). This was particularly true for Gwyneth Ho, a former journalist for the recently closed online media Stand News who won a seat in the District Council election in 2019 and is currently detained on several national security charges. After covering the LegCo occupation on 1 July 2019 and the 721 Yuen Long MTR Incident (during which she was beaten in front of her million viewers by a mob-affiliated thug), she became an extremely popular figure, given the affectionate nickname 'Stand News sister' (立場姐姐) (Stand News 2019). During the assault, she collapsed on the ground with her camera, but continued livestreaming without interruption, and the clip went viral.

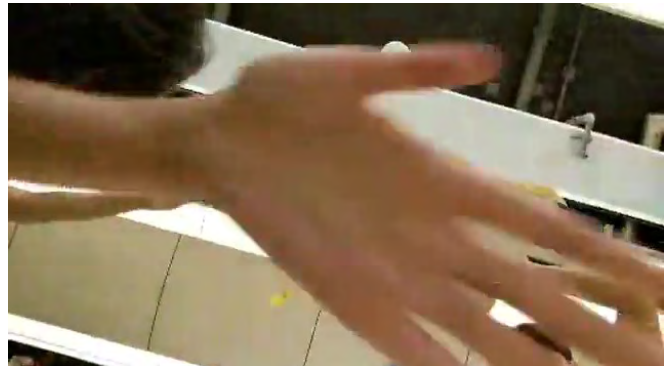

Screenshot from Gwyneth Ho's livestream for Stand News as she was being attacked at Yuen Long MTR Station (Stand News 2019).

Following the implementation of the NSL, the nature of the risks journalists face has changed dramatically. Editors and journalists have been arrested and several prodemocracy media outlets have been forcibly or preventively shut: Apple Daily in June 2021, Stand News in December 2021, and Citizen News (眾新聞) in January 2022. Other news organisations had already moved out of Hong Kong (for instance, Initium Media 端傳 媒), undergone radical transformation (RTHK), or failed to obtain visas for their foreign journalists. With these closures, not only are Hongkongers unable to choose their news sources, but also countless videos, reports, and visual depictions of the protests have been wiped from their original websites.

\section{Performances and Ghostly Presences}

To pre-empt legal problems, many independent filmmakers recording protest actions such as those depicted in Inside the Red Brick Wall used framing and other strategies such as digital blurring to protect the identities of their protagonists. As a result, these films are strikingly and purposefully devoid of the character portrayal techniques usually found in observational documentaries (Pernin 2021).

While these are the characteristics of the films focusing on young radical protesters (勇 武 jungmou) during the most eventful actions, 


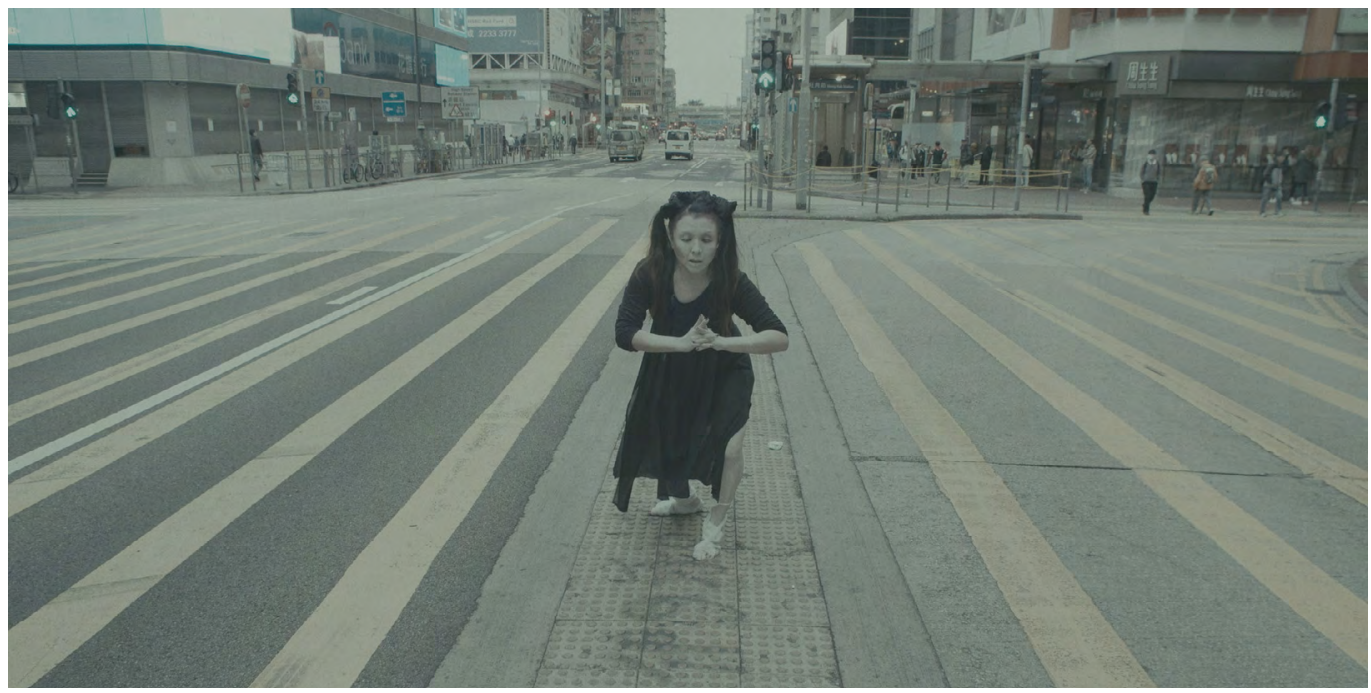

Vinci Mok's butoh performance in Fear(less) and Dear (2021). Courtesy Anson Mak.

other documentaries take the opposite approach to reflect on the personal struggles of the wo lei fei 和理非 generation-a term referring to those protesters who took a less confrontational approach. For instance, in Fear(less) and Dear (誠惶(不)誠恐, 親愛的; Mak 2021), sound artist and filmmaker Anson Mak gives voice to three artists who are also parents of young children. In three sections dedicated, respectively, to performance artist and former district councillor Clara Cheung, political comic artist Justin Wong, and writer Cheung Yuen-man, the director asks them about their fears, and they end up talking about the impact of the movement on their family, their professional life, and their creativity, and how they see Hong Kong's future. The film's slow and reflective pace invites us into the lives of ordinary families facing dilemmas about education, financial survival, and political positioning in a city haunted by protest memories. Among these conversations, Mak inserts scenes of Vinci Mok's butoh dance performances on the streets. She moves against the grim urban background that was once the stage for massive marches, using road fences to support her ghostly body while cars pass, bringing to the surface traumatic memories of the protests. The film also highlights the political role of Hong Kong artists with a recording of a 2015 performance by Clara Cheung. A few years before running for district councillor in 2019, Cheung broke 1,000 eggs on her body in front of the LegCo 'as a protest on the day when 689 (Chief Executive CY Leung) presented his policy address' (Guthrie 2016).

Well connected to their international and mainland peers, Hong Kong performance artists have long been involved in local social movements and prodemocracy activities (Wen 2018; To 2019). They were often spotted taking part individually or collectively in demonstrations such as the 1 July march and, on the evenings leading up to the 4 June commemoration, artist and researcher Wen Yau and others routinely staged street performances near Victoria Park, where the now defunct Hong Kong Alliance in Support of Patriotic Democratic Movements of China（香港市民支援愛國民 主運動聯合會) once organised the candlelit vigil. Artists such as Sanmu Chan and Kacey Wong were particularly active during the 2019 protests, which saw the former detained in mainland China and the latter choosing self-exile in Taiwan (Artforum 2019; Shaw 2021). Ephemeral and generally poorly recognised and understood, performance art allows Hong Kong practitioners to push the boundaries of freedom of speech. Voicing the democratic 
aspirations of their local audience in a public but implicit manner requires them to find ever more subtle forms of expression to avoid legal trouble.

\section{The Afterlives of Hong Kong Protests Visual Culture}

Before the introduction of the NSL, protest recordings and artistic productions about the prodemocracy movement were thriving on Hong Kong university campuses, in the media, among civil society, and in the cultural sphere at large. In retrospect, their virality and ubiquity seem to have at once fostered and been undermined by Hong Kong's special administrative status and the ambiguities of the 'One Country Two Systems' principle. Echoing Ackbar Abbas's (1997) muchquoted theory on Hong Kong cinema and culture, one could say these images belong to the nostalgic sphere of the 'déjà disparu' of the NSL era. Yet, as much as it seems fitting, this assessment also feels self-defeating and fails to consider the boundless creativity of Hongkongers in handling protest images and building their own visual culture. With the exile of many high-profile and ordinary activists, a de-territorialised space of resistance continues to press on political issues. Film screenings, debates, marches, and political satire remain alive abroad, and protest culture is still produced and consumed in Hong Kong, even though in a more private way, using more implicit and anonymous forms and on a smaller scale.

Since the implementation of the NSL, images of the 2019 protest movement have begun a new life. The records of street actions that fuelled social media exchanges and provided information in real time on the evolution of the protests are now part of the collective memory and live on in backups and memory drives. In the case of prodemocracy news clips and livestreams, most of the sites from which they originated are shut, but, fortunately, they were archived by Hong Kong citizens on repository websites. While this archiving effort cannot remedy the enormous loss of free media or the ease with which protest videos were previously circulated, it also shows that protest visual culture cannot completely be wiped out-just as political graffiti and Lennon walls remain as traces and photographs. Hong Kong's protest visual culture survives in memories and circulates in disguisefor instance, in a music clip combining images of Carrie Lam's press conferences and the 831 Prince Edward MTR attack in an abstract ghostly outline (Fong 2019), or as a 3D virtual reconstruction of the Pillar of Shame (Chaigne 2021).

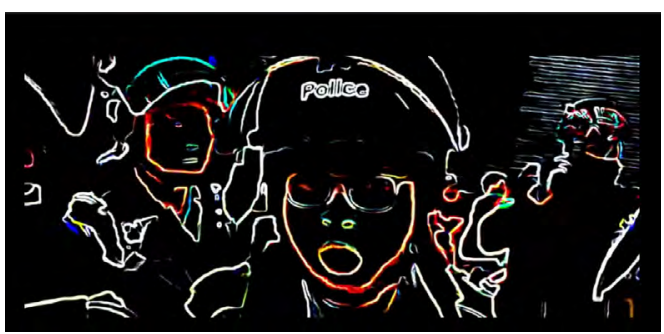

Footage of riot police turned into outlines. Screenshot from Fong (2019).

Digital archives and museum preservation initiatives are particularly crucial to keep a record of the political atmosphere and social creativity during the protests, allowing a better understanding of Hong Kong's history in the future. This, however, might not be possible in Hong Kong itself. In a city with a new, yet heavily monitored museum of visual culture, it is doubtful any of the imagery of the 2019 protests will manage to slip through the censors' net. Yet, we should not feel hopeless. While deplorable, this turn to ephemeral, implicit, anonymous, de-territorialised, digitised, and archived forms indicates that protest visual culture is not going to simply disappear in Hong Kong, but rather, a new regime of visibility and new forms of expression will emerge in response to political changes to resist complete erasure. 
This text is taken from Made in China Journal: Volume 6, Issue 3, 2021, edited by Ivan Franceschini, Nicholas Loubere and Shui-yin Sharon Yam, published 2022 by ANU Press, The Australian National University, Canberra, Australia.

doi.org/10.22459/MIC.06.03.2021.12 